\title{
Reasons for not adhering to cervical cancer screening guidelines and HPV knowledge among HIV indeterminate midlife women (50-64 years old) whose last Pap test was $>6$ years ago
}

\author{
Lisa T Wigfall ${ }^{1 *}$, Heather M Brandt ${ }^{1}$, Donna L Richter ${ }^{1}$, Wayne A Duffus ${ }^{2,3}$, Saundra H Glover ${ }^{1}$ \\ From $12^{\text {th }}$ International Conference on Malignancies in AIDS and Other Acquired Immunodeficiencies \\ (ICMAOI)
}

Bethesda, MD, USA. 26-27 April, 2010

\section{Background}

Oncogenic human papillomavirus (HPV) infection is a main cause of cervical cancer. Annual Pap tests are recommended for HIV-positive women because their risk of developing cervical cancer, an AIDS defining illness, is increased [1]. Poor uptake of routine HIV testing combined with poor adherence to recommended Pap test screening guidelines among midlife women (5064 years old) with late-diagnosed HIV infection increases their risk of being diagnosed with cervical cancer [2]. Women who miss opportunities for early initiation of effective antiretroviral therapy and early detection of precancerous cells face a double jeopardy of being diagnosed with HIV/AIDS and cervical cancer in late disease stages, when treatment is less successful.

\section{Materials and methods}

National Health Interview Survey (NHIS) 2008 data were analyzed to describe reasons for not adhering to recommended cervical cancer screening guidelines and HPV knowledge of midlife women who had never been tested for HIV and whose last Pap test was more than 6 years ago. Frequencies and weighted percents are reported.

\section{Results}

The sample included 224 midlife women. Of the $20 \%$ who had an abnormal Pap test $(n=42)$, only $1(<1 \%)$

\footnotetext{
*Correspondence: lisa.wigfall@sc.edu

${ }^{1}$ Arnold School of Public Health, University of South Carolina, Columbia,

SC, USA

Full list of author information is available at the end of the article
}

reported having a previous diagnosis of HPV infection. A third (33\%) did not have a Pap test in the past 6 years $(\mathrm{n}=65)$ because they had a hysterectomy, including $11 \%$ who had an abnormal Pap test $(n=20)$. Only $12 \%(n=14)$ of those who did not have a hysterectomy $(n=115)$ were planning to get a Pap test within a year. Most of these women $(40 \%)$ had no specific reason for not having a more recent Pap test (Table 1). For many other women (32\%), poor adherence was attributed to health care access issues (Table 1). HPV knowledge: $60 \%$ had heard of HPV $(n=129) ; 64 \%$ knew HPV caused cervical cancer $(\mathrm{n}=82)$; $60 \%$ knew HPV was spread through sexual contact $(n=79)$; and $85 \%$ did not think that HPV would go away without treatment $(\mathrm{n}=111)$.

Table 1 Reasons for not having a Pap test in the last 6 years, NHIS $2008(n=115)^{a}$

\begin{tabular}{llllll}
\hline Reasons & \multicolumn{2}{l}{$\begin{array}{l}\text { Abn } \\
\text { Pap }\end{array}$} & \multicolumn{2}{l}{$\begin{array}{l}\text { No Abn } \\
\text { Pap }\end{array}$} & Total \\
\hline & $\mathrm{n}$ & $\%^{\mathrm{b}}$ & $\mathrm{n}$ & $\%^{\mathrm{b}}$ & $\%^{\mathrm{b}}$ \\
$\begin{array}{l}\text { No reason/didn't think about it/put it } \\
\text { off/didn't get to it/don't know }\end{array}$ & 2 & 1.2 & 35 & 38.8 & 40.0 \\
$\begin{array}{l}\text { Cost was too expensive/no insurance/ } \\
\text { didn't have a doctor }\end{array}$ & 6 & 4.4 & 32 & 27.8 & 32.2 \\
$\begin{array}{l}\text { Didn't need/doctor didn't order it/not } \\
\text { having any problems }\end{array}$ & 2 & 3.7 & 17 & 11.5 & 15.2 \\
$\begin{array}{l}\text { Too painful, unpleasant, or embarrassing } \\
\text { Other }\end{array}$ & 1 & 0.9 & 4 & 2.6 & 3.5 \\
\hline
\end{tabular}

amissing $(n=7) ;{ }^{b}$ weighted percent 


\section{Conclusions}

Despite increased prevalence of HIV/AIDS, routine HIV testing is underutilized. Older adults are disproportionately burdened with late-diagnosed HIV infection. Early diagnosis of HIV and precancerous cervical cells due to HPV infection improves health outcomes for women. Dual HIV and cervical cancer prevention messages that target midlife women are needed.

\section{Acknowledgements}

This article has been published as part of Infectious Agents and Cancer Volume 5 Supplement 1, 2010: Proceedings of the $12^{\text {th }}$ International Conference on Malignancies in AIDS and Other Acquired Immunodeficiencies (ICMAOI). The full contents of the supplement are available online at http://www.biomedcentral.com/1750-9378/5?issue=S1.

\section{Author details}

${ }^{1}$ Arnold School of Public Health, University of South Carolina, Columbia,

SC, USA. ${ }^{2}$ Division of Infectious Diseases, University of South Carolina, School of Medicine, Columbia, SC, USA. ${ }^{3}$ HIV/STD Division, South Carolina

Department of Health and Environmental Control, Columbia, SC, USA.

Published: 11 October 2010

\section{References}

1. Chaturvedi AK, et al: . JNCI 2009, 101:1120-1130.

2. Oster RM, et al: . JAIDS 2009, 51(4):430-436.

Cite this article as: Wigfall et al:: Reasons for not adhering to cervical cancer screening guidelines and HPV knowledge among HIV indeterminate midlife women (50-64 years old) whose last Pap test was $>6$ years ago. Infectious Agents and Cancer 2010 5(Suppl 1):A68.

\section{Submit your next manuscript to BioMed Central} and take full advantage of:

- Convenient online submission

- Thorough peer review

- No space constraints or color figure charges

- Immediate publication on acceptance

- Inclusion in PubMed, CAS, Scopus and Google Scholar

- Research which is freely available for redistribution

Submit your manuscript at www.biomedcentral.com/submit 